\title{
Deontological Culture of Teachers of Medical Higher Educational Establishments: Preliminary Remarks
}

\author{
Author's Contribution: \\ A - Study design; \\ B - Data collection; \\ C - Statistical analysis; \\ D - Data interpretation; \\ E-Manuscript preparation; \\ F - Literature search; \\ $\mathbf{G}$ - Funds collection
}

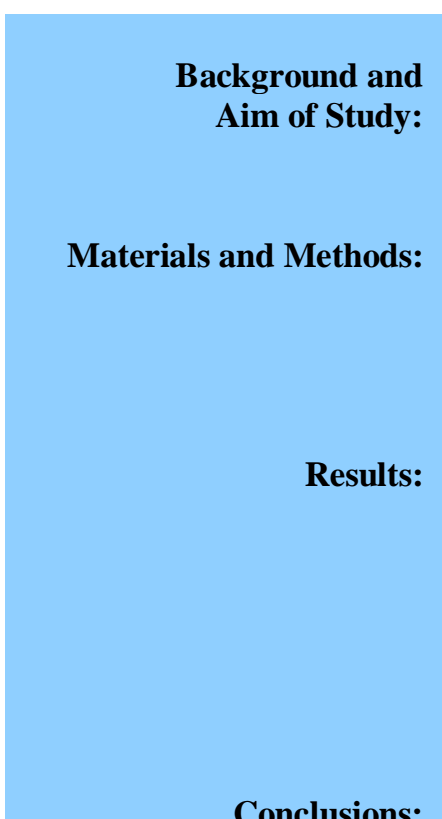

Conclusions:

Keywords:

Copyright:

DOI and UDC

Conflict of interests:

Peer review:

Source of support:

Information about

the author:

\author{
Yevtushenko Yu. O. ${ }^{1}$ ABDEFG
}

${ }^{1}$ Luhansk State Medical University, Ukraine

Received: 25.01.2019; Accepted: 26.02.2019; Published: 30.03.2019

\section{Abstract}

The article deals with the analysis of the problem of formation of deontological culture of teachers of medical higher educational establishments.

The aim of the study: to outline the key points of the problem of the formation of deontological culture of teachers of medical higher educational institutions.

A number of theoretical methods of analysis were employed in order to reveal the essence of the analyzed phenomenon, namely analytical review of scientific literature of Ukrainian and foreign scholars which deals with the problem of formation of deontological culture of teachers of higher educational institutions, theoretical analysis of the content and structure of the phenomenon in question, etc.

The author insists that one of the most important components in the professional activity of teachers of medical higher educational establishments, apart from purely medical knowledge, skills and habits, is connected with their pedagogical competence. Thus, there appears a problem of formation of pedagogical competence of teachers of medical educational institutions in general and their deontological pedagogical culture in particular. It goes about the necessity to form deontological culture of teachers of medical higher educational establishments which lies in the medical and pedagogical space.

The author arrives at the conclusion that deontological culture in modern social and cultural conditions acts as an important social and personal resource of humanization of the system of education and a teacher's professional activity. The problem-thematic space of the analysis of deontological culture of teachers of medical higher educational establishments is open for studying and needs further theoretical and applied solutions aimed at searching new technological mechanisms of the development in conditions of a multi-aspect pedagogical environment and intensification of the processes in the sphere of education.

deontological culture, teachers of medical higher educational establishments, moral and ethical principles, content and structure of deontological culture, educational process.

(C) 2019 Yevtushenko Yu. O. Published by Archives of International Journal of Education and Science

DOI 10.26697/ijes.2019.1.03; UDC 378.124:614.25

The author declares that there is no conflict of interests

Double-blind review

Departmental sources

Yevtushenko Yuliia Oleksandrivna (Corresponding Author) - https://orcid.org/00000002-7315-3337; julia.evtyshenko@ukr.net; Doctor of Philosophy in Pedagogy, Head of the Department of Medical and Biological Physics, Medical Informatics and Biostatistics; Luhansk State Medical University; Rubizhne, Ukraine. 


\section{Introduction}

Deontology, or deontological ethics (from the Greek $\delta$ Éov - due, appropriate) which was born at the beginning of the XIX century due to the efforts of the English philosopher Bentham (1748-1832) as a philosophical theory on the problems of morality and human duty which is preconditioned by the ethic values, nowadays is mainly analyzed in the context of the professional activity of doctors. The ways of the solution of the problem of formation of deontological culture of future specialists in the medical sphere are represented in numerous scientific works written by the Ukrainian and foreign scholars among whom it is worth mentioning the following names: Avrakhova (2003); Fedorova (2016); Gavrylkevych (2011); Geraimovych (2008); Kolesnyk-Humeniuk (2013); Krasnov (2006); Kundiev (2009); Litvinenko (2010); Musii (2015); Pyrih (2007); Tymoshchiuk (2004); Vainola (2010); Volosovets (2004); Yasko (2004), etc. In our previous scientific research (Yevtushenko, 2017), it was found out that deontological culture of future doctors is a complex personal and professional quality of a future doctor which forms his moral awareness (a combination of moral values and ethic standards which become his personal convictions and aim his professional activity at the formation and reflection of the moral and ethical demands of the society in the sphere of health protection), which is constantly formed, reconsidered and improved in the process of professional activity of specialists of the medical sphere.

However, a further scientific interest makes another problem. In Ukraine, there exist a great many of institutions of higher education which deal with professional training of teachers of different specialities: foreign languages, artistic disciplines, exact and natural sciences, etc. At the same time no one university in Ukraine prepares teachers to work at medical educational establishments. It is especially connected with those who teach disciplines of practical training of future doctors. As a rule, former graduates from medical universities who received a sufficient scientific and practical experience in the sphere of medicine later become teachers of medicine.

On the other hand, we cannot help taking into account the fact that one of the most important components in the professional activity of teachers of medical higher educational establishments, apart from purely medical knowledge, skills and habits, is connected with their pedagogical competence. Thus, there appears a problem of formation of pedagogical competence of teachers of medical educational institutions in general and their deontological pedagogical culture in particular. It goes about the necessity to form deontological culture of teachers of medical higher educational establishments which lies in the medical and pedagogical space.

The aim of the study. To outline the key points of the problem of the formation of deontological culture of teachers of medical higher educational establishments.

\section{Materials and Methods}

To achieve the aim a set of theoretical methods were employed, namely: analytical review of scientific literature of Ukrainian and foreign scholars which deals with the problem of formation of deontological culture of teachers of higher educational institutions, theoretical analysis of the content and structure of the phenomenon in question, etc.

\section{Results and Discussion}

In the context of our research, it is worth paying attention to the results of modern scientific analyses made by the Ukrainian and foreign scholars in the center of which lies the problem of the formation of deontological culture of teachers of higher educational institutions.

For instance, in the works by Karahanova (2007); Kravtsov (2011); Rohr (2009); Romanyshyna and Telychko (2015); Vasylieva (2004) and others it is stressed that deontological culture of a teacher represents a social and pedagogical phenomenon which is a result of his morally oriented training that takes into account the demands of his professional and pedagogical responsibilities which is revealed in his professional behavior and activity. The content of deontological culture of a teacher, as the scholars think, is represented as a dialectal unity of the axiological, technological and individually creative components.

The axiological component is formed with the help of a combination of pedagogical values created by the mankind which are involved into the integral pedagogical process. The technological component embraces the means, ways, methods and forms of a teacher's pedagogical activity. The individually creative component of the deontological culture reveals the mechanisms of acquiring pedagogical values and technologies and their implementations as a creative act.

We cannot but agree with the idea expressed by Romanyshyna and Telychko (2015) that the main foundation of the formation of pedagogical professionalism of teachers are reflected in their professionally significant features that have a humanistic orientation, for the lack of them can hardly be compensated by any perfect knowledge or professional and pedagogical skills because a personal position of a real teacher is a foundation for the formation of his pedagogical skills.

We strongly believe that a teacher's deontological culture, including that of teachers of medical higher educational establishments, must be defined according to the following criteria, namely:

1. A value-based attitude to the pedagogical activity which is revealed in the awareness of the value of pedagogical knowledge, in the declaration of the priority of subject-subject relations, in the satisfaction received from the pedagogical activity.

2. A pedagogical readiness which presupposes acquiring different kinds of pedagogical activity and such pedagogical skills as the reflective, prognostic, organizational, informational ones, etc. 
3. A teacher's creative activity which is realized in the growing dynamics, flexibility and variability of pedagogical thinking, independence in making decisions, the formed pedagogical reflection, acquisition of the experience of perfection.

Criteria of a teacher's deontological culture is presented in Figure 1.

It goes without saying that in the context of the solution of the problem of formation of deontological culture of teachers of medical higher educational institutions it is impossible to simply transfer the existing results of the scientific research in the sphere of pedagogical deontology into the educational process of medical universities. It is necessary to take into account the specificity of the organization of the educational process of a medical higher establishment, the lack of pedagogical education at a great number of teachers of medical higher educational institutions which could be an efficient foundation for the formation of their deontological culture. However, the main thing in the context of the solution of this problem is the interaction and interpenetration of the medical deontology into the pedagogical one and vice versa.

We would like to stress that deontological culture is a notion created for a concrete professional activity and situation that occupies a special place in the educational system of a medical higher educational establishment. It is well-known that both teachers and doctors are engaged in the process of training of future specialists in this sphere (Zhukovskiy, 2015). Thus, there appears an interlacing of two professional systems of morality: the medical and the pedagogical ones (Atamanchuk, 2006). In this case, the deontological culture of a teacher consists of the professional ethics of a teacher and a doctor. It means that a teacher must be able to professionally combine the values that belong to these two professional cultures. In the medical and pedagogical ethics, there exist points of contact that make it possible to represent the deontological culture as a sum of professional components of a doctor and a teacher (Mandal, Ponnambath, \& Parija, 2016).

The problem of formation of deontological culture of a teacher of medical higher educational establishment gets a special significance in conditions of construction of a humane society which, in its turn, reveals the role of the human factor in a new way (Bykova, 2012). This process is first of all represented in establishing subject-subject relations in which the student does not become an object of teaching but its subject with his own inner world, the system of values, individual peculiarities, etc. At the same time the communication between the student and teacher is viewed upon not only as an interaction but as a mutual influence on one another (Çipi \& Meksi, 2013).

Thus, we think that a high level of deontological culture together with the professional skills and habits is an inseparable part of the professional competence of a teacher of educational establishment being one of the main criteria of his vocational fitness (Zhukovskiy \& Ilkovskaya, 2013).

It is the moral and ethic postulates that in modern conditions become the main guidelines of the pedagogical activity that allow directing the vector of a teacher's educational efforts to the sphere of a harmonious and all-round development of the personality of a student (Ramos, 2011).

In conditions of the modern educational pattern, a teacher does not act as a simple translator of knowledge but as a personality who ensures the realization of the functions of a guide of the educational activity of his students in the teaching process with the basis on the role-playing behavior which lies in the professional and deontological plane of pedagogical activity (Rosić, 2011).

Deontological standards in this case function as the guidelines and restraints of pedagogical influences in concrete pedagogical situations which ensure the fulfillment of professional norms in the aspect of pedagogical duty and responsibility for the results of the professional activity.

In the works of Ukrainian and foreign scholars in different periods of the historical development, the problems connected with the requirements to a teacher's personality, the fulfillment of his professional duties were actively analyzed (Chernyshevskiy; Gertsen; Komenský; Locke; Makarenko, 1951; Melnyk, 2017; Pestalozzi, 1961-1965; Quintilianus; Rousseau; Socrat; Sukhomlinskiy; Ushinskiy, 1974; and others). These works served a theoretical foundation for understanding and defining the content of the deontological direction in pedagogy.

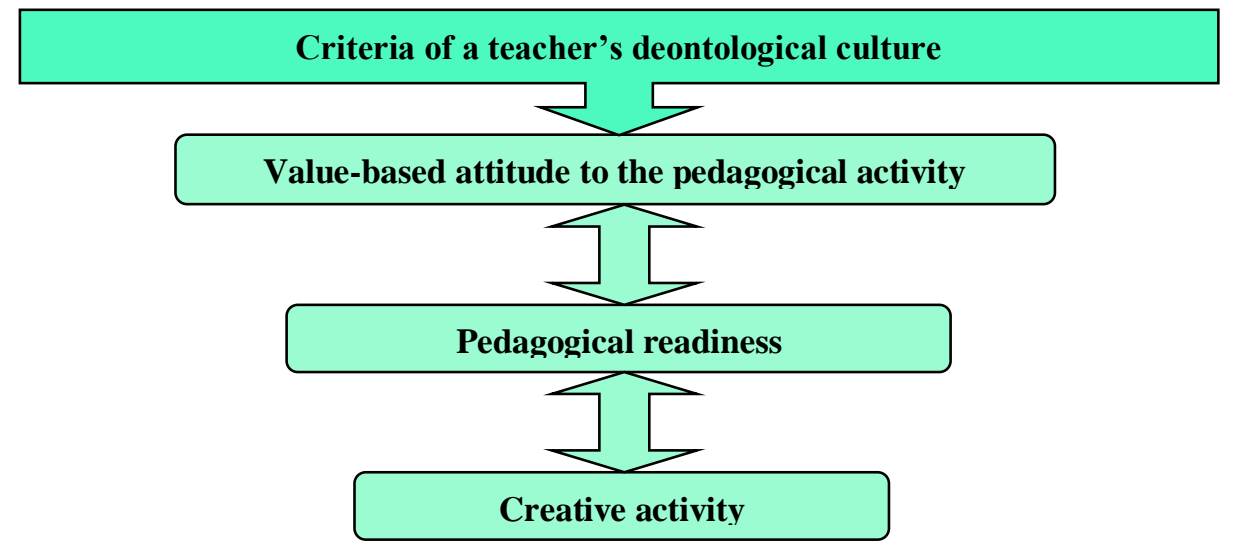

Figure 1. Criteria of a teacher's deontological culture. 
According to Pestalozzi (1961-1965), a teacher's duty consists in the formation of an individual who will be useful for a society and who will be harmoniously developed. The scholar assumed that a teacher is the main subject who creates a favorable atmosphere in the educational establishment at the expense of exclusion of authoritarianism and excessive regulations.

Ushinskiy (1974), speaking about the duty of an educator, stated that his main function must consist in striving to learn and cognize the pupil's individuality in all its variety which will allow detecting the mechanisms of pedagogical impact on him.

The position of Makarenko (1951) is connected with the idea that a teacher performing certain actions must be aware of what he is doing and must base on such qualities as tactfulness, mutual trust and responsibility. The latter means manifestation of mutual relationships between the subjects of a certain community which is characterized by understanding socially significant standards that lie in the space of deontological axioms (juridical, moral and ethical, behavioral ones) (Starov, 2011).

The principle of trust directs a teacher's activity at building the relations with the pupils that are based on mutual acceptance of one another, taking into account the incoming information and patterns of behavior in concrete situations. The principle of empathy presupposes a spiritual unity of a teacher and a pupil based on an integral moral and ethical line of mutual understanding and interaction. The principle of justice assumes that a teacher must assess his students according to their real achievements without being biased against them on the one side and without overestimating them on the other one.

On the basis of the discriminated principles, the firstpriority requirements to a teacher from the point of view of the deontological aspect of his pedagogical activity are as follows: humanistic orientation of a teacher's personality within the framework of which there take place understanding and interiorization of pedagogical actions, strengthening of moral landmarks; existence of professional and personal deontological qualities that allow a teacher organizing his pedagogical activity and ensuring a steadfast behavior in accordance with his professional duty; deontological position of a teacher as an integration of his attitudes to education, to the role that he performs in this sphere, to himself and to his pupils as active subjects of the educational space based on the awareness of his professional and pedagogical duty which is revealed in the moral orientation of the professional activity and socially significant behavior (Zhukovskiy \& Ilkovskaya, 2013).

The stated above requirements are the landmarks of a teacher's role-playing behavior that define his social and professional successfulness, the efficiency of the trajectory of his personal development and growth and that characterize the deontological culture of a pedagogue.

Deontological culture is an important component of a broader formation - a teacher's professional culture which was thoroughly analyzed in the scientific and theoretical pedagogical literature (see the works by Derkach, 2004; Ivanov, 1988; Kuznetsov, 1997; Markova, 1995; Melnyk \& Pypenko, 2018; Ogarev, 1995; etc.).

Analyzing the notion of deontological culture, we would like to emphasize that according to Filatova (2015) it represents an integral subject characteristic that consists in the theoretical, applied and personal readiness of a teacher for his professional activity on the basis of following standards and rules of professional behavior.

As Bykova (2012) and Kostomarova (2014) see it, deontological culture is a systemic personal quality which includes knowledge, skills, habits, outlook and moral ideals and standards of professional behavior aimed at ensuring a teacher's readiness to fulfill his professional duty.

Treating the notion of a teacher's deontological culture we state that it represents an integral personal formation characterized by the presence of a system of competences and which reflects juridical and moral and ethical aspects of pedagogical activity, personal and professional qualities that ensure maintenance and cultivation of standards and rules of professional behavior on the basis of a conscious professional duty in the educational space.

Investigating the content of deontological culture, we point out the following first-priority aspects of its study in its problem field that make up the essence of the further structural arrangement of the notion under analysis: the juridical one, the behavioral one, and the ethical one.

It is worth paying attention that the content of the juridical aspect of the deontological culture of a teacher of a medical higher educational establishment is connected with the new legislative initiative in the system of medical education that focus on the anthropological component of his professional activity which is laid upon moral and ethical priorities.

The behavioral aspect of studying deontological culture is based on the idea of ensuring an individual stability of a pedagogue's behavior resistant to the negative factors of the professional environment, able to preserve psychological and behavioral stability in the professional activity. Stability in this case is viewed upon as a complex of qualities of a pedagogue that ensure his social successfulness at the expense of his abilities to realize active behavioral forms of reactions in different pedagogical situations.

It is obvious that pedagogical activity is full of difficult and often stressful situations which can lead to the change of the traditional, regulatory forms of behavior, can cause specific behavioral reactions, and can destabilize a person's psychological state. That is why a teacher must have skills to predict variants of the development of the situation, plan the routes of his own behavior as well the reactions of other participants of the educational process, work out preventive measures connected with the preservation of his personal stability.

At the same time a teacher has to 1) be ready to react to the changes taking place inside of the educational 
system; 2) be confident in the correctness of the chosen route of behavior; 3 ) personally choose variants of behavioral reactions; 4) be able to regulate his own psychic states by means of using mechanisms of problem-oriented coping, still stages within the borders of following juridical and ethical standards of his professional activity (Zhukovskiy, 2015).

Speaking about the content of the ethical aspect of studying deontological culture, we would like to note that the sphere of pedagogical activity represents a unique moral space and acts as a specific regulator of its moral foundations and peculiarities of applications of educational endeavors of a teacher and his interactions with other participants of educational relations. In this connection, it is quite obvious that a teacher must possess certain moral qualities and moral responsibility in the process of his pedagogical activity. Without going deep into the analysis of moral qualities of an individual (they are rather explicitly expanded in the works by Baryshnikova (2015); Bibler (1990); Boldyrev (1994); Bondarevskaya (1995); Jakobson (2006); Kolesnikova (2002); Korosten (2009); Zhukovskaya (2006) and others), we would like to state that their main essence consists in affirmation of the inner aware necessity to fulfill the moral and ethical demands worked out by the society which makes it possible to motivate the pedagogical activity on the basis of moral responsibility.

We find important the statement made by Atamanchuk (2006) who believes that if a teacher does not have a moral responsibility, he will not be able to achieve any kind of responsibility at all. Following the idea of the scholar, we think that it can result in a destructive attitude towards the pedagogical activity and disability to solve out contradictions and to achieve success. We define moral responsibility as a teacher's interiorization of the social and moral demands, the social necessity for pedagogical actions, the awareness of their consequences for himself, for the students and for the whole sphere of professional activity.

\section{Conclusions}

Summing up the stated above, we would like to emphasize that deontological culture in modern social and cultural conditions acts as an important social and personal resource of humanization of the system of education and a teacher's professional activity. The problem-thematic space of the analysis of deontological culture of teachers of medical higher educational establishments is open for studying and needs further theoretical and applied solutions aimed at searching new technological mechanisms of the development in conditions of a multi-aspect pedagogical environment and intensification of the processes in the sphere of education.

Thus, one of the topical tasks that modern scholars face nowadays is connected with the analysis of the theoretical and methodological foundations of the formation of deontological culture of teachers of medical higher educational institutions on the basis of which it would be possible to work out a concept of formation of the analyzed phenomenon in the educational process of medical universities of Ukraine.
References

Atamanchuk, G. V. (2006). Teorija gosudarstvennogo upravlenija [Theory of state governance: a course of lectures]. Moscow: Omega-L. [in Russian]

Bykova, S. S. (2012). Formirovanie deontologicheskoj kompetentnosti u budushhih pedagogov $\mathrm{V}$ sisteme professional'nogo obrazovanija [Formation of deontological competence of future pedagogues in the system of professional education]. Vestnik Vjatskogo Gosudarstvennogo Gumanitarnogo Universiteta - Bulletin of Vyatka State Humanitarian University, 3(4), 37-41. [in Russian]

Çipi, B., \& Meksi, S. (2013). Medical ethics. Tirana: Klean.

Filatova, I. A. (2015). Deontologicheskaja kompetentnost' budushhih pedagogovdefektologov [Deontological competence of future pedagogues-speech philologists]. Special'noe obrazovanie - Special education, 2, 105-115. [in Russian]

Karahanova, G. A. (2007) Formirovanie deontologicheskoj kul'tury uchitelja $v$ sisteme nepreryvnogo professional'nogo obrazovanija [Formation of deontological culture of a teacher in the system of a continuous professional education] (Doctoral dissertation, Russian State Social University, Moscow, Russia). [in Russian]

Kertaeva, K. M. (2002). Osnovy pedagogicheskoj deontologii [Foundations of pedagogical deontology]. Almaty. [in Russian]

Kostomarova, E. V. (2014). Deontologicheskaja kompetentnost' studenta-medika kak faktor uspeshnost' professional'noj dejatel'nosti vracha [Deontological competence of a medical student as a factor of successfulness of professional activity of a doctor]. Izvestija Volgogradskogo Gosudarstvennogo Pedagogicheskogo Universiteta - Bulletin of Volgograd State Pedagogical University, 4(89), 134-138. [in Russian]

Kravtsov, V. O. (2011). Deontolohichna kultura yak skladova metodolohichnoi kultury maibutnoho vchytelia [Deontological culture as a component of methodological culture of a future teacher]. Naukovi zapysky KDPU. Pedahohichni naukyScientific Bulletin of KDPU. Pedagogical Sciences, 101, 21-30. [in Ukrainian]

Makarenko, A. S. (1951). Sochinenija [Collection of works]. Moscow. [in Russian]

Mandal, J., Ponnambath, D. K., \& Parija, S. C. (2016). Utilitarian and deontological ethics in medicine. Tropical Parasitology, 6(1), 5-7. doi:10.4103/2229-5070.175024

Melnyk, Yu. (2017). Study of trends of students' demand for the formation of competences by higher educational institutions. Science and Education, 5, 128-134. doi:10.24195/24144665-2017-5-22

Melnyk, Yu. B., \& Pypenko, I. S. (2018). Training of future specialists in higher education 
institutions. International Journal of Science Annals, 1(1-2), 4-11. doi:10.26697/ijsa.2018.12.01

Pestalozzi, I. G. (1961-1965). Izbrannye pedagogicheskie proizvedenija [Selected pedagogical works]. Moscow. [in Russian]

Ramos, F. (2011). Professional deontology in teacher training. Report on a training experience. Publicaciones. Facultad de Educación y Humanidades Campus de Melilla, 41, 9-31.

Rohr, J. (2009). French deontology. Public Administration Review, 69(1), 143-145. doi:10.1111/j.1540- 6210.2008.01952.x

Romanyshyna, L. M., \& Telychko, N. V. (2015). Problema deontolohii u formuvanni profesiinoetychnoi kultury yak skladovoi zahalnoi kultury fakhivtsia [Problem of deontology in professional and ethical culture as a component of a general culture of a specialist]. Visnyk Natsionalnoi akademii Derzhavnoi prykordonnoi sluzhby Ukrainy - Bulletin of the National Academy of Border Guards Service, 2. Retrieved from http://nbuv.gov.ua/UJRN/Vnadps_2015_2_17 [in Ukrainian]

Rosić, V. (2011). Teacher's deontology. The Basis of the Pedagogical Ethics, 44, 142-149.

Starov, M. I. (2011). Otvetstvennost' kak vazhnaja psihologo-pedagogicheskaja sostavljajushhaja duhovno-nravstvennogo razvitija lichnosti studenta [Responsibility as an important psychological and pedagogical component of spiritual and moral development of student's personality]. Vestnik Tambovskogo universiteta. Gumanitarnye nauki - Bulletin of Tambov University. Humanitarian Sciences, 104(12-2), 593-596. [in Russian]

Ushinskiy, K. D. (1974). Izbrannye pedagogicheskie sochinenija [Selected pedagogical works]. Moscow: Pedagogika. [in Russian]

Vasylieva, M. P. (2004). Teoretychni osnovy deontolohichnoi pidhotovky pedahoha [Theoretical foundations of deontological training of a pedagogue] (Abstract of Doctoral dissertation, H. S. Skovoroda Kharkiv National Pedagogical University, Kharkiv, Ukraine). [in Ukrainian]

Yevtushenko, Yu. O. (2017). Formuvannia deontolohichnoi kultury maibutnikh likariv $u$ navchalno-vykhovnomu protsesi medychnoho $V N Z$ [Formation of deontological culture of future doctors in the educational process of a medical higher educational establishment] (Doctoral dissertation, Taras Shevchenko Luhansk National University, Starobilsk, Ukraine). [in Ukrainian]

Zhukovskiy, V. P., \& Ilkovskaya, I. M. (2013). Deontologicheskij aspekt pedagogicheskoj dejatel'nosti: novye orientiry rolevogo povedenija uchitelja [Deontological aspect of pedagogical activity: new guidelines of roleplaying behavior of a teacher]. Aktual'nye problemy vospitanija detej $i$ molodezhi $v$ sovremennoj Rossii - Topical problems of education of children and youth in modern Russia (pp. 33-38). Saratov. [in Russian]

Zhukovskiy, V. P. (2015). Transsituativnaja ustojchivost' povedenija pedagoga $\mathrm{V}$ sovremennom obrazovatel'nom prostranstve: teoretiko-metodologicheskie osnovanija razvitija [Trans-situational stability of behavior of a pedagogue in modern educational space: theoretical and methodological foundations of development]. Edinaja obrazovatel'naja sreda kak faktor socializacii obuchajushhihsja: Ch. 1. - United educational environment as a factor of socialization of students: P. 1 (pp. 173-178). Saratov: SOIRO. [in Russian]

\section{Література}

Атаманчук Г. В. Теория государственного управления. Москва: Омега-Л, 2006. 584 с.

Быкова С. С. Формирование деонтологической компетентности у будущих педагогов в системе профессионального образования. Вестник

Вятского государственного гуманитарного университета. 2012. Т. 3. № 4. С. 37-41.

Çipi B., Meksi S. Medical Ethics. Tirana: "Klean", 2013.

Филатова И. А. Деонтологическая компетентность будущих педагогов-дефектологов. Специальное образование. 2015. № 2. С. 105115.

Караханова Г. А. Формирование деонтологической культуры учителя в системе непрерывного профессионального образования: дис. ... дра пед. наук: 13.00.08/Рос. гос. социал. ун-т. Москва, 2007. 410 с.

Кертаева К. М. Основы педагогической деонтологии. Алматы, 2002. 238 с.

Костомарова Е. В. Деонтологическая компетентность студента-медика как фактор успешность профессиональной деятельности врача. Известия Волгоградского государственного педагогического университета. 2014. № 4 (89). С. 134-138.

Кравцов В. О. Деонтологічна культура як складова методологічної культури майбутнього вчителя. Наукові записки КДПУ. Сер. Педагогічні науки. 2011. Вип. 101. С. 21-30.

Макаренко А. С. Сочинения: в 5 т. Москва, 1951. T. 5.

Mandal J., Ponnambath D. K., Parija S. C. Utilitarian and deontological ethics in medicine. Tropical Parasitology. 2016. Vol. 6. Iss. 1. P. 5-7. doi:10.4103/2229-5070.175024

Melnyk Yu. Study of trends of students' demand for the formation of competences by higher educational institutions. Science and Education. 2017. № 5. P. 128-134. doi:10.24195/24144665-2017-5-22

Melnyk Yu. B., Pypenko I. S. Training of future specialists in higher education institutions. 
International Journal of Science Annals. 2018. Vol. 1. № 1-2. P. 4-11. doi:10.26697/ijsa.2018.1-2.01

Песталоцци И. Г. Избранные педагогические произведения: в 3 т. Москва, 1961-1965. 1932 c.

Ramos F. Professional deontology in teacher training. Report on a training experience. Publicaciones. Facultad de Educación y Humanidades Campus de Melilla. 2011. № 41. P. 9-31.

Rohr J. French deontology. Public Administration Review. 2009. Vol. 69. № 1. P. 143-145. doi:10.1111/j.1540- 6210.2008.01952.x

Романишина Л. М., Теличко Н. В. Проблема деонтології у формуванні професійноетичної культури як складової загальної культури фахівця. Вісник Національної академї Державної прикордонної служби Украӥни. $2015 . \quad$ Вип. $2 . \quad$ URL: http://nbuv.gov.ua/UJRN/Vnadps_2015_2_17 (дата звернення 20.01.2019).

Rosić V. Teacher's deontology. The basis of the pedagogical ethics. 2011. Vol. 44. P. 142-149.

Старов М. И. Ответственность как важная психолого-педагогическая составляющая духовнонравственного развития личности студента. Вестник Тамбовского университета. Сер. Гуманитарные науки. 2011. T. 104. № 12-2. С. 593-596.

Ушинский К. Д. Избранные педагогические сочинения: в 2 т. Москва: Педагогика, 1974. $1024 \mathrm{c}$.

Васильєва М. П. Теоретичні основи деонтологічної підготовки педагога: автореф. дис. на здобуття наук. ступеня д-ра пед. наук: 13.00.04. Харків, 2004. 43 с.

Євтушенко Ю. О. Формування деонтологічної культури майбутніх лікарів у навчальновиховному процесі медичного ВНЗ: дис. ... канд. пед. наук: 13.00.04/ДЗ “Луган. нац. унт ім. Тараса Шевченка”. Старобільськ, 2017. 242 c.

Жуковский В. П., Ильковская И. М. Деонтологический аспект педагогической деятельности: новые ориентиры ролевого поведения учителя. Актуальные проблемь воспитания детей и молодежи в современной России. Саратов, 2013. С. 3338.

Жуковский В. П. Трансситуативная устойчивость поведения педагога в современном образовательном пространстве: теоретикометодологические основания развития. Единая образовательная среда как фактор соииализаџии обучающихся: сб. материалов науч.-практ. конф. Ч. 1. Саратов: СОИРО, 2015. C. $173-178$.

\begin{abstract}
Деонтологічна культура викладачів вищих медичних закладів освіти: попередні зауваження Свтушенко Ю. О. ${ }^{1}$

1 Луганський державний медичний університет, Україна
\end{abstract}

\begin{abstract}
Анотація
Bступ: Теоретично обтрунтовано актуальність дослідження проблеми формування деонтологічної культури викладачів вищих медичних закладів освіти. Мета дослідження: Окреслити ключові аспекти проблеми формування деонтологічної культури викладачів медичних університетів. Матеріали і Методи: У дослідженні використано низку теоретичних методів аналізу, зокрема: теоретичний аналіз сутності та структурі досліджуваного педагогічного явища, аналіз наукової літератури вітчизняних та зарубіжних фахівиів з проблеми формування деонтологічної культури викладачів вищих навчальних закладів. Результати: У дослідженні доведено, щзо однією $з$ найважливіших складових у професійній діяльності викладачів медичних закладів вищої освіти, окрім суто медичних знань, навичок та вмінь, $\epsilon$ їхя педагогічна компетентність. Отже, перед науковиями постає завдання з формування педагогічної компетентності викладачів медичних закладів освіти у цілому та їх деонтологічної педагогічної культури зокрема. Йдеться про те, щзо проблема формування деонтологічної культури викладачів медичних закладів вищої освіти переходить у медико-педагогічну площчну. Висновки: Актуальним завданням перед науковиями стає вивчення теоретикометодологічних основ формування деонтологічної культури у викладачів медичних закладів вищої освіти, на основі яких можна було б розробити концепцію формування досліджуваного явища в освітньому процесі медичних університетів України.
\end{abstract}

Ключові слова: деонтологічна культура, викладачі вищих медичних закладів освіти, морально-етичні принциипи, зміст та структура деонтологічної культури, освітній процес.

\section{Cite this article as:}

Yevtushenko, Yu. O. (2019). Deontological Culture of Teachers of Medical Higher Educational Establishments: Preliminary Remarks. International Journal of Education and Science, 2(1), 22-28. doi:10.26697/ijes.2019.1.03

The electronic version of this article is the complete one and can be found online at: http://ijes.culturehealth.org/index.php/en/archive

This is an Open Access article distributed under the terms of the Creative Commons Attribution License, which permits unrestricted use, distribution, and reproduction in any medium, provided the original work is properly cited (http://creativecommons.org/licenses/by/4.0/deed.en). 